\title{
The Internal Structure of Human Capital of China's Economic Growth
}

\author{
Zhixin XUE, Xiaojing CHAO \\ Northwest University, Xi'an, China \\ \{xuezhixin0106, chaoxiaojing1234\}@163.com
}

\begin{abstract}
In the process of economic development, professional human capital plays a key role and general human capital plays a supporting role. The both of them have a different impact on economic growth. This paper divides the human capital into professional human capital and general human capital according to the difference between the proportion of educated population at different levels, through the quantile regression, and has empirically studied the relationship between human capital at different levels and economic growth on the panel data of 30 provinces (except Hong Kong, Macao, Taiwan and Tibet) in China from 1998 to 2015. The results have shown that the increase of internal structure of human capital plays a positive role in promoting economic growth, and the positive effect of internal structure of human capital on the economic growth is decreased with the increase of the quantile.
\end{abstract}

Keywords: Internal Structure of Human Capital, Professional Human Capital, General Human Capital, Economic Growth.

\section{Introduction}

With the coming of knowledge economy, as a competitive resource, the advantage of human capital has gradually emerged, and the brain economy has been the mainstream of the development of economy in the world. Since the 19th National Congress of the Communist Party of China (CPC), China has entered a pivotal stage with characteristics of transforming economic structure, improving economic structure and fostering new drivers of growth. Especially the increase of human capital has become an essential factor contributing to the high-quality economic development because the traditional demographic dividend of China is wearing off at present. Thus we should focus more on human capital. So human capital in China should change in which direction? How does the human capital at different levels influence chinese economic growth? The study could help us to understand the current situation of the internal structure of human capital in China and provide new thoughts for the internal structure of human capital's driving force to promote economic growth. 


\section{$2 \quad$ Literature Overview}

Human capital has indelible influences on the long-term economic growth $[2,4,7]$. Most of the existing literature about the concept of the human capital and economic growth is studied from the following two aspects: on the one hand, some studies analyze the relation of human capital and economic growth. There are mainly three kinds of views: Firstly, from the perspective of technological progress, it is believed that human capital has indirect effect on economic growth due to the progress of the technology $[16,20]$. Secondly, from the perspective of "dual effect" of human capital, it considers that human capital could influence economic growth through accumulating and learning because of the knowledge spillover [12, 18]. Thirdly, from the perspective of economic structure, with the structural characteristics of the economy, it states that human capital affects the economic growth. And human capital has an obvious influence on the economic growth only if the development of human capital should agree with its economic structure [1, 15]. On the other hand, some studies analyze the internal structure of the human capital to economic growth. It considers that the economic growth is correlated with the internal structure of human capital which reflects the difference in the quality of labor. The one used generalized least squares to analyze the relationship between the human capital and human capital structure and the regional economic growth from 1990 to 2004. The result showed that human capital structure can only promote economic growth in a few areas, and the vast regions relied on material capital to promote economic growth [9]. The one defined the difference between high-skilled workers and low-skilled workers as the human capital structure, and studied the factors of realizing the equilibrium between the two countries in the open economy. It showed that human capital structure was the factor which affected the comparative advantage between the two countries, and the human capital structure determines the channels of comparative advantage through the matching of labor skills and departments ${ }^{[13]}$. There was a study researching on the effect of educational human capital on economic growth used data from 1996 to 2010. The result showed that education human capital could obviously promote economic growth ${ }^{[10]}$. Through combing the literatures, we find that most of them focus on the mean-value regression, but pay less attention to the influence of conditional distribution on independent variables. In addition, in the existing literature, there are different views about the division of the internal structure of human capital, many scholars generally use the years of education to divide human capital $[5,6,11]$. And some scholars divide the human capital according to the difference in education earning rate $[14,17]$. Some scholars use the structure of labor demand to divide the human capital structure $[3,19]$. We can see that they lack considerations of differences in the quantity of human capital.

Based on that, this paper defines the professional human capital which is indicated by the percentage of population with higher education and general human capital which is indicated by the percentage of population with non-higher education, and then we select panel data from 1998 to 2015 to analyze the relationship between the internal structure of human capital and economic growth. 


\section{Model Specification}

\subsection{Construction of the Economic Model}

On the basis of existing literature, there is a correlation between the internal sturcture of human capital and economic growth. And we establish the benchmark model as follows:

$$
\operatorname{Lnpergdp}_{i t}=\alpha+\beta_{1} s_{i t}+\lambda X_{i t}+\mu_{i}+v_{i t}
$$

where the subscrip $i$ and $t$ distiguish the area and time, per capita real GDP can be

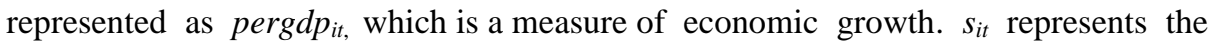
internal structure of human capital, which means the proportion of professional human capital and general human capital. And $X_{i t}$ is a vector of variables indicating for the impact of other factors which affect economic growth including: $k_{i t}$ represents the actual stock of physical capital, $L_{i t}$ represents the total workforce, $p u b_{i t}$ represents the proportion of public service expenditure, $\operatorname{trad}_{i \mathrm{t}}$ represents trade openness, ind $\mathrm{it}_{\text {it }}$ represents the industrial structure, which measures the high-grade of industrial structure, mar $_{i t}$ epresents the owership structure, old ${ }_{i t}$ represents the proportion of the elderly dependent ratio, $c_{i t}$ represents consumption rate, $t f p_{i t}$ represents rate of total factor productivity.

Then, this paper further uses the quantile regression for panel data to analyze the impact of internal structure of human capital on economic growth in different quantile, so as to comprehensively reflect the conditional distribution of the internal structure of human capital and economic growth and exclude extreme values. Thus the econometric model is specified as following:

$$
\operatorname{Lnpergdp}_{i t}=\alpha+\beta_{1}(q) s_{i t}+\lambda(q) X_{i t}+\mu_{i}+v_{i t}
$$

where $q$ distiguishes different quantiles which equal to $0.25,0.5,0.75,0.95$.

\subsection{Data and Variables}

In this paper, we use the data of sample period (1998-2015) as the empirical basis covering 30 provinces except Hong Kong, Macao, Taiwan and Tibet. Then, The explained variable is expressed by the actual per capita output (pergdp). The core explanatory variable refers to human capital internal structure $(s)$, which is computed by the professional human capital level divided by general human capital level, where the level of professional human capital and the level of general human capital are defined as the proportion of higher education population and the proportion of nonhigher education population.

In addition, the study uses all control variables including: the actual stock of physical capital $(k)$ refers to calculated by using the research methods ${ }^{[8]}$; Total workforce $(L)$ refers to the number of employment in all provinces; Proportion of public service expenditure $(p u b)$ refers to the proportion of public service expenditure to finance expenditure; Trade openness ( $\operatorname{trad}$ ) refers to the proportion of total value of imports and exports to GDP; Industrial structure (ind) refers to represented with the 
proportion of tertiary industry to secondary industry; Structure of ownership (mar) refers to the proportion of non-state-owned assets in fixed assets investment; Proportion of the elderly dependent ratio (old) refers to the proportion of the old people aged 65 years and more than 65 years in the labor force; Consumption rate $(c)$ refers to the proportion of consumption expenditure to total expenditure; Rate of total factor productivity ( $t f p)$ is calcuated by the index of Malmquist, solved with DEAP2.1, where the output indicator is represented by the per capita output, investment indicators are represented by the actual stock of physical capital and total workforce.

The study is drawn from data on China Statistical Yearbook (1998-2015), Date of Gross Domestic Product of China (1952-2004) and Statistical Yearbook for regions. some population data are obtained from China Population Yearbook (1998-2015). Besides, we give descriptive statistics on the correlated variables from 1998 to 2015 (see Table 1).

Table 1. Descriptive statistics of variables.

\begin{tabular}{ccccccc}
\hline Variable & Province & $\mathrm{N}$ & Mean & St.d & Min & Max \\
\hline pergdp & 30 & 540 & 8133.03 & 8453.36 & 220.92 & 52342.03 \\
$s$ & 30 & 540 & 0.10 & 0.09 & 0.01 & 0.73 \\
$k$ & 30 & 540 & 182.36 & 197.99 & 3.67 & 1176.75 \\
$L$ & 30 & 540 & 24.49 & 16.42 & 2.54 & 66.36 \\
pub & 30 & 540 & 11.05 & 3.85 & 3.48 & 30.89 \\
trad & 30 & 540 & 11.05 & 3.85 & 3.48 & 30.89 \\
ind & 30 & 540 & 0.96 & 0.44 & 0.50 & 4.04 \\
mar & 30 & 540 & 0.62 & 0.14 & 0.16 & 1.00 \\
old & 30 & 540 & 12.00 & 2.52 & 6.13 & 21.88 \\
$c$ & 30 & 540 & 52.59 & 8.86 & 36.07 & 89.4 \\
tfp & 30 & 540 & 1.01 & 0.22 & 0.47 & 1.90 \\
\hline
\end{tabular}

\section{$4 \quad$ Empirical Results}

\subsection{Results of the Benchmark Model}

We firstly analyze the relationship between the internal structure of human capital and economic growth with the data of 30 provinces (1998-2015) in China, using the fixed effect model, random effect model, ordinary least square (OLS) model and system generalized method of moments(GMM) model to do empirical test (see Table 2). The results of fixed effects, random effect and the ordinary least square are reported in Table 2 (columns 1-3), the result shows that the coefficient of $s$ is significantly positive at the 1 level, indicating that the internal structure of human capital has a 
significantly effect on the economic growth. And the results of the system GMM estimation are reported in Table 2 (column 4), it shows that the original model can be set for the system GMM estimation because it is accord with the original hypothesis of the autocorrelation test and Sargan test. And the coefficient of $s$ is also positive at 1 level from the estimation result, which is consistent with the results of the above model.

In terms of control variables, the coefficients of $k, L$, mar, trad is significantly positive, indicating that the physical capital stock, total workforce, ownership structure and trade openness have positive effect on economic growth. The coefficient of $c$ and ind are negative and statistically significant, and the coefficient of tfp is not significant. However, the coefficient of old is positive and significant in the fixed effects, random effect and ordinary least square model except in the system GMM model. The coefficient of $p u b$ is significantly negative in the fixed effects, random effect and ordinary least square model, but contrary to the system GMM model. Because the one-period lag variable of economic growth as a tool variable which improves the accuracy of model in the dynamic panel regression. It may be due to the poor willingness of the residents. So the lack of consumer demand leads to a negative effect on economic growth. And the negative relationship between the industrial structure and economic growth may be caused by the fact that the secondary industry still plays important role on the economic growth.

Table 2. Regression results of China's internal structure of human capital and economic growth.

\begin{tabular}{|c|c|c|c|c|}
\hline $\begin{array}{l}\text { Estima- } \\
\text { tion }\end{array}$ & $\begin{array}{c}\text { (1) } \\
\text { Fixed effects }\end{array}$ & $\begin{array}{c}\text { (2) } \\
\text { Random effects }\end{array}$ & $\begin{array}{l}\text { (3) } \\
\text { OLS }\end{array}$ & $\begin{array}{c}(4) \\
\text { System GMM } \\
\text { (twostep) }\end{array}$ \\
\hline L.pergdp & & & & $\begin{array}{l}0.968^{* * *} \\
(0.005)\end{array}$ \\
\hline$s$ & $\begin{array}{l}3.254^{* * *} \\
(0.253)\end{array}$ & $\begin{array}{l}3.267^{* * * *} \\
(0.251)\end{array}$ & $\begin{array}{c}3.328^{* * *} \\
(0.373)\end{array}$ & $\begin{array}{c}0.082^{* * *} \\
(0.013)\end{array}$ \\
\hline$k$ & $\begin{array}{l}0.001^{* * *} \\
(0.000)\end{array}$ & $\begin{array}{l}0.001^{\text {**** }} \\
(0.000)\end{array}$ & $\begin{array}{c}0.001^{* * * *} \\
(0.000)\end{array}$ & $\begin{array}{c}0.000^{* * * *} \\
(0.000)\end{array}$ \\
\hline$L$ & $\begin{array}{l}0.025^{* * *} \\
(0.006)\end{array}$ & $\begin{array}{c}0.030^{* * * *} \\
(0.003)\end{array}$ & $\begin{array}{c}0.030^{* * * *} \\
(0.002)\end{array}$ & $\begin{array}{c}0.002^{* * *} \\
(0.000)\end{array}$ \\
\hline$p u b$ & $\begin{array}{c}-0.011^{* * *} \\
(0.003)\end{array}$ & $\begin{array}{c}-0.012^{* * *} \\
(0.003)\end{array}$ & $\begin{array}{c}-0.014^{* * *} \\
(0.005)\end{array}$ & $\begin{array}{c}0.001^{* * *} \\
(0.000)\end{array}$ \\
\hline ind & $\begin{array}{c}-0.157^{* * *} \\
(0.062)\end{array}$ & $\begin{array}{c}-0.176^{* * * *} \\
(0.059)\end{array}$ & $\begin{array}{c}-0.400^{* * *} \\
(0.065)\end{array}$ & $\begin{array}{c}-0.068^{* * *} \\
(0.005)\end{array}$ \\
\hline mar & $\begin{array}{l}1.734^{* * * *} \\
(0.133)\end{array}$ & $\begin{array}{r}1.691^{* * * *} \\
(0.130)\end{array}$ & $\begin{array}{r}0.940^{* * * *} \\
(0.207)\end{array}$ & $\begin{array}{c}0.167^{* * * *} \\
(0.014)\end{array}$ \\
\hline
\end{tabular}




\begin{tabular}{|c|c|c|c|c|}
\hline old & $\begin{array}{c}0.021^{* * *} \\
(0.007)\end{array}$ & $\begin{array}{c}0.024^{* * *} \\
(0.006)\end{array}$ & $\begin{array}{c}0.051^{* * * *} \\
(0.008)\end{array}$ & $\begin{array}{l}-0.000 \\
(0.000)\end{array}$ \\
\hline$c$ & $\begin{array}{c}-0.018^{* * * *} \\
(0.002)\end{array}$ & $\begin{array}{c}-0.018^{\text {**** }} \\
(0.002)\end{array}$ & $\begin{array}{c}-0.014^{* * *} \\
(0.003)\end{array}$ & $\begin{array}{c}-0.001^{* * * *} \\
(0.000)\end{array}$ \\
\hline$t f p$ & $\begin{array}{c}0.020 \\
(0.036)\end{array}$ & $\begin{array}{c}0.020 \\
(0.036)\end{array}$ & $\begin{array}{c}0.034 \\
(0.077)\end{array}$ & $\begin{array}{l}-0.005 \\
(0.001)\end{array}$ \\
\hline trad & $\begin{array}{c}0.172^{* * *} \\
(0.076)\end{array}$ & $\begin{array}{c}0.180^{* * *} \\
(0.070)\end{array}$ & $\begin{array}{c}0.296^{* * * *} \\
(0.057)\end{array}$ & $\begin{array}{c}0.011^{* * * *} \\
(0.005)\end{array}$ \\
\hline _cons & $\begin{array}{l}7.268^{* * *} \\
(0.206)\end{array}$ & $\begin{array}{l}7.138^{* * *} \\
(0.186)\end{array}$ & $\begin{array}{c}7.235^{* * *} \\
(0.239)\end{array}$ & $\begin{array}{c}0.335^{* * *} \\
(0.039)\end{array}$ \\
\hline $\mathrm{AR}(1)$ & & & & $\begin{array}{c}-0.283 \\
(0.777)\end{array}$ \\
\hline $\mathrm{AR}(2)$ & & & & $\begin{array}{c}-0.187 \\
(0.852)\end{array}$ \\
\hline sargan & & & & $\begin{array}{c}28.704 \\
(0.926)\end{array}$ \\
\hline $\mathrm{N}$ & 510 & 510 & 510 & 480 \\
\hline $\mathrm{R}^{2}$ & 0.912 & 0.912 & 0.866 & \\
\hline $\begin{array}{l}\text { Haus- } \\
\text { man }\end{array}$ & $\begin{array}{c}5.3 \\
(0.87)\end{array}$ & & & \\
\hline Wald & & 4993.13 & & $3.89 \mathrm{e}+06$ \\
\hline $\mathrm{F}$ & 488.97 & & 323.58 & \\
\hline
\end{tabular}

Notes: Data is calculated by Stata15.0.

***,**, * significant respectively at 1 percent, 5 percent, 10 percent level.

\subsection{Results of the Extended Model}

Considering that the quantile regression is the method of weighted average of the absolute value of residual, which has less effect on the extreme value. Furthermore, compared to mean reversion, it can more clearly observe the effect of the internal structure of human capital on economic growth. This paper further uses the panel quantile regression to estimate the impact of the internal structure of human capital on economic growth by using panel data from 1998 to 2015 in China, and verifies whether internal structure of human capital has different impact on economic growth in different quantile. We analyze the relationship between the internal structure of human capital and economic growth in provinces by selecting representative quantiles which are $0.25,0.5,0.75$ and 0.9 . The quantile regression results are shown in Table 3. 
Table 3. Quantile regression results of China's internal structure of human capital and economic growth.

\begin{tabular}{|c|c|c|c|c|}
\hline $\begin{array}{c}\text { Explanatory } \\
\text { variables }\end{array}$ & $\begin{array}{c}\text { (1) } \\
\text { QR_25 }\end{array}$ & $\begin{array}{c}\text { (2) } \\
\text { QR_50 }\end{array}$ & $\begin{array}{c}(3) \\
\text { QR_75 }\end{array}$ & $\begin{array}{c}(4) \\
\text { QR_90 }\end{array}$ \\
\hline$s$ & $\begin{array}{c}3.585^{* * * *} \\
(0.678)\end{array}$ & $\begin{array}{c}2.615^{* * *} \\
(0.557)\end{array}$ & $\begin{array}{c}2.475^{* * * *} \\
(0.659)\end{array}$ & $\begin{array}{c}1.096 \\
(0.686)\end{array}$ \\
\hline$k$ & $\begin{array}{c}0.001^{* * * *} \\
(0.000)\end{array}$ & $\begin{array}{l}0.002^{* * *} \\
(0.000)\end{array}$ & $\begin{array}{l}0.002^{* * *} \\
(0.000)\end{array}$ & $\begin{array}{l}0.003^{* * * *} \\
(0.000)\end{array}$ \\
\hline$L$ & $\begin{array}{c}0.029^{* * * *} \\
(0.003)\end{array}$ & $\begin{array}{c}0.023^{* * *} \\
(0.002)\end{array}$ & $\begin{array}{c}0.017^{* * *} \\
(0.002)\end{array}$ & $\begin{array}{c}0.012^{\text {**** }} \\
(0.002)\end{array}$ \\
\hline pub & $\begin{array}{l}-0.010 \\
(0.017)\end{array}$ & $\begin{array}{l}-0.003 \\
(0.008)\end{array}$ & $\begin{array}{l}-0.008 \\
(0.006)\end{array}$ & $\begin{array}{l}-0.009^{*} \\
(0.005)\end{array}$ \\
\hline trad & $\begin{array}{l}0.228^{* *} \\
(0.109)\end{array}$ & $\begin{array}{c}0.317^{* * * *} \\
(0.079)\end{array}$ & $\begin{array}{c}0.366^{* * * *} \\
(0.042)\end{array}$ & $\begin{array}{c}0.325^{\text {**** }} \\
(0.045)\end{array}$ \\
\hline ind & $\begin{array}{c}-0.484^{* * *} \\
(0.148)\end{array}$ & $\begin{array}{c}-0.384^{* * * *} \\
(0.115)\end{array}$ & $\begin{array}{c}-0.437^{* * * *} \\
(0.124)\end{array}$ & $\begin{array}{l}-0.232^{*} \\
(0.128)\end{array}$ \\
\hline mar & $\begin{array}{l}0.846^{*} \\
(0.457)\end{array}$ & $\begin{array}{l}1.264^{* * *} \\
(0.186)\end{array}$ & $\begin{array}{l}1.206^{* * * *} \\
(0.256)\end{array}$ & $\begin{array}{c}0.949^{* * * *} \\
(0.235)\end{array}$ \\
\hline old & $\begin{array}{c}0.053^{* * *} \\
(0.018)\end{array}$ & $\begin{array}{c}0.028^{* * *} \\
(0.009)\end{array}$ & $\begin{array}{c}0.025^{\text {**** }} \\
(0.007)\end{array}$ & $\begin{array}{c}0.013^{\text {*** }} \\
(0.006)\end{array}$ \\
\hline$c$ & $\begin{array}{l}-0.010^{*} \\
(0.006) \\
\end{array}$ & $\begin{array}{c}-0.011^{* * * *} \\
(0.003) \\
\end{array}$ & $\begin{array}{l}-0.008^{*} \\
(0.004) \\
\end{array}$ & $\begin{array}{l}-0.006^{*} \\
(0.003) \\
\end{array}$ \\
\hline$t f p$ & $\begin{array}{c}0.050 \\
(0.132)\end{array}$ & $\begin{array}{c}0.057 \\
(0.067)\end{array}$ & $\begin{array}{c}0.010 \\
(0.049)\end{array}$ & $\begin{array}{l}-0.026 \\
(0.049)\end{array}$ \\
\hline _cons & $\begin{array}{l}6.902^{* * * *} \\
(0.386)\end{array}$ & $\begin{array}{l}7.233^{\text {**** }} \\
(0.180)\end{array}$ & $\begin{array}{l}7.503^{* * *} \\
(0.273)\end{array}$ & $\begin{array}{l}7.869^{\text {**** }} \\
(0.234)\end{array}$ \\
\hline $\mathrm{N}$ & 510 & 510 & 510 & 510 \\
\hline Pseudo $\mathrm{R}^{2}$ & 0.634 & 0.672 & 0.691 & 0.706 \\
\hline Wald & \multicolumn{4}{|c|}{9.5} \\
\hline
\end{tabular}

Notes: Data is calculated by Stata15.0. Weed out missing values. The standard error of bootstrap is enclosed in brackets.

***,**,* significant respectively at 1 percent, 5 percent, 10 percent level.

As shown in Table 3, the estimated results are mostly in line with the results of Table 2. Specifically, the contribution coefficient of the internal structure of human capital to economic growth is significantly positive in the 1 percent significance level except for 90 percent of the quantile. It shows that the internal structure of human capital has significantly positive effect on economic growth, which is close to the reality. Because the general human capital which is mainly made up of simple labor would gradually transform to the professional human capital with social development, then the internal structure of human capital would develop a uptrend along with economic 
development. In addition, the material capital and total workforce are significantly positive at each quantile. The regression coefficient of the proportion of public service expenditure passes a 10 percent significance level and positive in 90 percent of the quantile, but has insignificant at 10 percent, 25 percent and 50 percent of the quantile. It demonstrates that the promotion of public service expenditure on economic growth is not significant, and it has not fully play its role in present period. The impact of trade openness on economic growth is markedly positive at each quantile. Industrial structure has the significantly negative effect on economic growth at 1 percent level which are in 25 percent, 50 percent and 75 percent of the quantile, while the coefficient of industrial structure only passes the 10 percent of the significant test in 90 percent of the quantile. Structure of ownership is positively correlated to economic growth, which passes a 1 percent significance test in 25 percent of the quantile, and the rest of them pass the significant test in the 1 percent significance level. It implies that the structure of increase the economic growth by the development of private enterprises. Proportion of the elderly dependent ratio has positively correlated relationship between economic growth at 25 percent, 50 percent, 75 percent and 90 percent of the quantile, because of the insufficient demand of household consumption. In this situation, the rise of proportion of the elderly population will actually increase in the consumption demand of the elderly, and it would drive to unleash new growth and stimulate the economy. While the rate of consumption is negatively related to economic growth with 1 percent significant level at 50 percent of the quantile, and the coefficient of cosumption rate passes the 10 percent significance level in 25 percent, 75 percent and 90 percent of the quantile, it also has a negative impact on economic growth. Rate of total factor productivity has a positive but not significant impact on economic growth at each quantile, showing that technical progress of production doesn't play the role of promoting the economic growth, the explanation of economic growth by the rate of total factor productivity is not obvious. So the improvement of rate of total factor productivity requires the progress of technology or the reallocation of resources.

In order to further compare the change of the internal structure of human capital on economic growth, this paper compares the regression coefficient and its confidence interval in different quantile with the coefficient of OLS estimation as a reference (see Fig.1). 

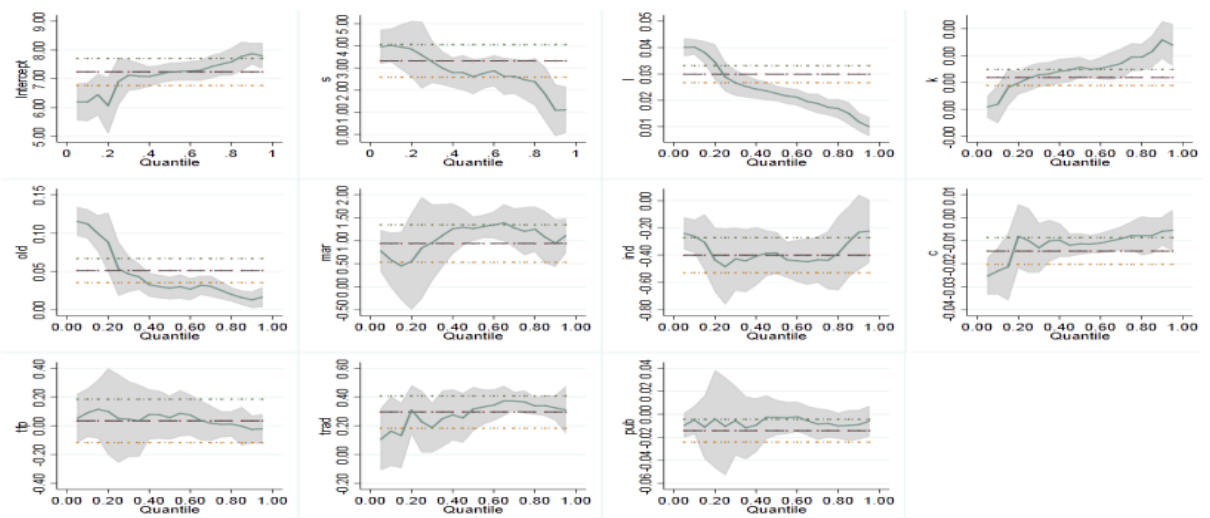

Fig. 1.The trend of regression coefficient in quantile regression.

According to the trend of regression coefficient in quantile regression model in Fig.1, the study shows that the regression coefficient of the internal structure of human capital generally has been declining with the increase of quantile, although it rises slightly after reaching 50 percent of the quantile. There is a clear demonstration, when the economy is at a low economic level, the more proportion of professional human capital, the promoting function of its economic growth is bigger. While the economy is at a high economic level, the promotion of professional human capital is gradually reduced with the rapid growth of economy. In addition, Fig.1 also illustrates that, for 95 percent confidence interval, the width of an interval for regression coefficient of internal structure of human capital from 10 percent of the quantile to 50 percent of the quantile is more narrow than the width after 50 percent of the quantile in the conditional distribution, which indicates the estimation of quantile regression coefficient in the intermediate value is stable, but it is more unstable near the endpoint of 90 percent of the quantile. In the control variables, the regression coefficients of the actual capital stock gradually increases from 10 percent to 90 percent of the quantile, and the positive effect of the actual capital stock on economic growth has been increasingly apparent with the economic development; The proportion of public service expenditure first ascends and then descends in cycle with the adding of the quantile, but the overall change extent is not apparent; The coefficient of owership structure and trade openness present like a "reverse U" which increase firstly after declining with the increase of the quantile. While the regression coefficient of industrial structure has an opposite trend. Proportion of the elderly dependent ratio and the total labor force are gradually decreasing, and its explanation to the economic growth is gradually weakened, but proportion of the elderly dependent ratio rises slightly after 90 percent of the quantile. The regression coefficient of consumption rate would increase with the quantile, while its absolute value presents downward trend. The regression coefficient of total factor growth rate periodically increases at the beginning, and decreases finally under the 95 percent confidence interval. 


\section{Discussion}

In order to find a new approach to growth in China's transitional period, this paper has used the quantile regression as experiment to examine whether the internal structure of human capital encourages economic growth. Compared with the existing research literature, this paper extends the existing research mainly from the following two aspects: Firstly, the existing literature often considers the internal structure of human capital from the perspective of the year of education or education earning rate or structure of labor demand. However, the quantity of human capital at different level is also one of the important factors which affect economic growth. Therefore, this paper considers that the human capital could be composed of professional human capital level and general human capital by the difference of the proportion of educated population. Secondly, most of the existing literatures are based on the traditional mean method to study the influence of human capital on economic growth. In this paper, we use panel quantile regression method to describe the relationship between internal structure of human capital and economic growth in different quantiles. The results indicate that the positive influence of human capital structure on economic growth gradually decreases with the increase of per capita output. Due to the limits of time and condition, this paper has many deficiencies, such as we there are no discussion about the effect of internal structure of human capital on economic growth in different regions and the robust test in the study, so we could do further study on this issue in the future.

\section{Conclusion}

Based on the panel data of China's 30 provinces (except Hong Kong, Macao, Taiwan and Tibet) from 1998 to 2015, this paper gives an empirical research on the relationship between the internal structure of human capital and China's economic growth. The empirical results show that the improvement of the professional human capital level in the internal structure of human capital has significantly positive effect on economic growth, and its promotion would be gradually weakened with increasing the per capita output. Therefore, this paper puts forward the following suggestions: On the one hand, Chinese government should pay more attention to cultivating highquality professional talent for enterprises and encourage small and medium enterprises to introduce professionals and motivate the employee's creativity on the base of meeting the development needs of all industries. It is helpful to embark on innovative activities and break through the bottleneck of further development of enterprises. On the other hand, Chinese government should speed up the transition of general human capital to professional human capital, in particular, providing more opportunities of further study for lower-middle class workers who engage in physical work, and encourage them to learn new science and technology, hence increasing the proportion of professional talents. 
Acknowledgements. This work was supported by National Social Science Fun (Grant No 13CJL012) and Program for New Century Excellent Talents in University (Grant No NCET-13-0952) and Humanities and Social Science Talent Plan in Shaanxi.

\section{References}

1. Čadil, J., Petkovová, L., Blatná, D.: Human capital, economic structure and growth. Procedia Economics and Finance (12), 85-92(2014), DOI: 10.1016.S2212-5671.

2. Choi, K., Shin, S.: Population aging, economic growth, and the social transmission of human capital: an analysis with an overlapping generations model. Economic Modeling 50(5), 138-147(2015), DOI:10.1016.j. econmod.2015.05.015.

3. Fang, F., Zhu, L.: Population structure, human capital structure and economic growth. Economic Theory and Business Management (8), 5-16(2013).

4. Pelinescu, E.: The impact of human capital on economic growth. Procedia Economics and Finance (22), 184-190(2015), DOI: 10.1016.S2212-5671.

5. Romer, P. M.: Endogenous technological change. Journal of Political Economy98(5), 71102(1990), DOI:10.1016.j.rser. 2015.12.176.

6. Huang, Y., Liu, Y., Wu, Y., Li, W.: Economic growth and regional inequality in China: Effects of different levels of education. Economic Research (4), 94-105(2013).

7. Hou, Y., Wang, J.: Human capital and transition in mode of economic growth. Population Research (5), 13-19(2005).

8. Lei, H.: Research on the measurement of capital stock and investment efficiency in China. Economist (6), 75-83(2009).

9. Li, X.: Human capital, human capital structure and regional coordinative development: the evidence from Chinese provinces. Journal of Central China Normal University (Humanities and Social Sciences) (3), 47-56(2007).

10. Luo, L., Yin, F.: Human capital structure and economic growth: an empirical study based on panel data model and threshold regression model. Journal of Jiangxi University of Fiance and Economics (2), 63-72(2013).

11. Wang, Y., Zhu, P.: The composition effect of human capital on regional economic growth in China. Nanjing Journal of Social Sciences (8), 18-25(2016).

12. Wang, Q.: Appropriate technology, human capital and regional knowledge spillover: empirical analysis based on panel data of China during 1995-2009. Technology Economics (6), 27-33(2012)

13. Shao, W., Li, K., Wang, Y.: Human capital structure, skill match and comparative advantage. Economic Review (1), 26-39(2015), DOI: 10.19361/j.er.2015.01.003.

14. Sun, B.: A new interpretation of the increasing rate of education returns in Chinaendogenous analysis of biased human capital based on technological progress [J]. Education Science (6), 1-4(2005), DOI:10.3969/j.issn.1002-8064.2005.06.001.

15. Wu, X., Zhou, X.: Demographic dividend, institutional dividend and China's economic growth. Reform of Economic System (3):11-16(2017).

16. Wang, D.: Health human capital, economic growth and poverty trap. Economic Research (6), 143-155(2012)

17. Tai, H., Cui, X.: Human capital structure and economic growth-an analysis based on transnational panel data. World Economic Papers (2), 48-71(2017).

18. Yao, X., Zhang, H.: Education, human capital and regional economic differentials. Economic Research (5), 47-57(2008). 
19. Yu, C.: Investment structure in human capital and economic growth-endogenous economic growth analysis based on education capital and health capital. Journal of Finance and Economics(10), 102-112(2006), DOI : 10.16538/j.cnki.jfe.2006.10.010.

20. Zhu, G: The impact of human capital agglomeration on technological progress: a literature review. Economic Research Guide (9), 196-197(2015). 